\title{
CLINICAL EVALUATION OF AYURVEDIC FORMULATION OF COLICARMIN PLUS SYRUP ON COLIC, GRIPING PAIN, INDIGESTION, NAUSEA, VOMITING, AND OTHER DIGESTIVE DISORDERS IN PAEDIATRICS AND GERIATRICS PATIENTS.
}

\author{
GIRISH H PATEL ${ }^{1}$, DEVENDRA MISHRA ${ }^{2 *}$, RUPALI GATHANI ${ }^{3 *}$
}

${ }^{1}$ Physician, $1^{\text {st }}$ Floor, Creative Chamber, Kanak Road, Rajkot, Gujarat, India. ${ }^{2}$ Product Executive, Department of Product Management, Ban Labs (P) Ltd., Rajkot, Gujarat, India. ${ }^{3}$ Regulatory Affairs Officer, Department of Regulatory Affairs, Ban Labs (P) Ltd., Rajkot, Gujarat, India. Email: productmanagement@banlab.com

Received: 24 May 2016, Revised and Accepted: 27 May 2016

\section{ABSTRACT}

Objective: An open label study to assess the effect of colicarmin plus syrup on colic and griping pain, indigestion, nausea and vomiting in children, and geriatric patients.

Methods: (a) A study was conducted on 75 number of patients to evaluate the effect of colicarmin plus syrup on colic and griping pain, indigestion, nausea and vomiting in children, and adults, (b) mostly these children were selected from different classes of families, (c) all the patients were checked on the $1^{\text {st }}, 2^{\text {nd }}$, and $3^{\text {rd }}$ week after starting the therapeutic dose.

Dosage schedule: (a) Children: 1 Teaspoonful thrice a day after meals, (b) adults: 2 Teaspoonful twice to thrice a day after meals.

Results: (a) Colic and griping pain: In the total duration of treatment, no of patients recovering were 23-on $1^{\text {st }}$ week, 4-on $2^{\text {nd }}$ week, and 3-on $3^{\text {rd }}$ week, overall result is $93.54 \%$, (b) indigestion: In the total duration of treatment, no of patients recovering were 26-on $1^{\text {st }}$ week, 3-on $2^{\text {nd }}$ week, and 1-on $3^{\text {rd }}$ week, the overall result is $93.75 \%$, (c) nausea and vomiting: In the total duration of treatment, no of patients recovering were 8-on $1^{\text {st }}$ week, 2-on $2^{\text {nd }}$ week, and 1 -on $3^{\text {rd }}$ week, the overall result is $91.33 \%$.

Conclusion: Based on the study, we can conclude that colicarmin plus syrup is an Ayurvedic formulation with benefits such as digestive, carminative, anthelmintic, antiflatulent, antispasmodic, and devoid of side effects.

Keywords: Digestive, Carminative, Anthelmintic, Antiflatulent and Antispasmodic.

(C) 2016 The Authors. Published by Innovare Academic Sciences Pvt Ltd. This is an open access article under the CC BY license (http://creativecommons. org/licenses/by/4. 0/) DOI: http://dx.doi.org/10.22159/ajpcr.2016.v9s2.13053

\section{INTRODUCTION}

Crying is a normal physiological behavior in children. In children, crying is a specific behavior which achieves its likely evolutionary function. The children cry for a variety of reasons including the need for attention, hunger, pain and discomfort of minor upsets such as flatulence, nausea, vomiting, or colic pain.

The word colic means spasm or painful tightening of muscle. Crying of children due to "colic" is often thought to be due to pain coming from the baby's tummy and bowel, but the bowel of babies with colic seems healthy.

Abdominal pain is one of the most common reasons for a parent to bring his or her child to medical attention. The evaluation of "tummy ache" can challenge both parents and pediatrics. Possible causes for a child's abdominal pain range from trivial to life-threating with little difference in the child's complaints. Fortunately, an abdominal pain in a child usually improves quickly $[1,2]$.

It is important to distinguish colic from specific disorders that can produce abdominal pain or cramping and prolonged crying including infection, food allergies, or intestinal obstruction. If no physical causes can be found, colic is usually the diagnosis [3].

Further, indigestion, diarrhea, gas, and other digestive problems are most commonly seen in adults and that may be caused by varied etiology. In addition, the gastrointestinal problem is characterized by abdominal pain. It is troublesome with a significant negative impact on quality of life and social functioning in many patients.

Some of the herbs have tendency to cure abdominal problems some of which are shown in Table 1.

Clinical trial of colicarmin syrup was carried out to check the efficacy against different symptomatic indications [4-11].

\section{METHODS}

The study was conducted on 75 number of patients to evaluate the effects of colicarmin plus drops on colic and griping pain, indigestion, nausea and vomiting in children, and adults. This was carried out at Dr. Girish Patel (M.D.) Hospital, Rajkot.

A total of 75 patients from children and adults were enrolled in the study. Mostly these children and adults were selected from different classes of families.

All the children and adults were followed up at frequent intervals for their indication, and the observations were noted at $1^{\text {st }}, 2^{\text {nd }}$, and $3^{\text {rd }}$ week of the therapeutic dose (Tables 2-4).

\section{Dosage schedule}

a. Children: 1 Teaspoonful 3 times a day after meals

b. Adults: 2 Teaspoonful 2-3 times a day after meals. 
The following observation has been made after administration of the therapeutic dose.

\section{RESULTS}

In the case of colic and griping pain after the treatment of 21 days, 93.54\% relief was observed (Fig. 1).

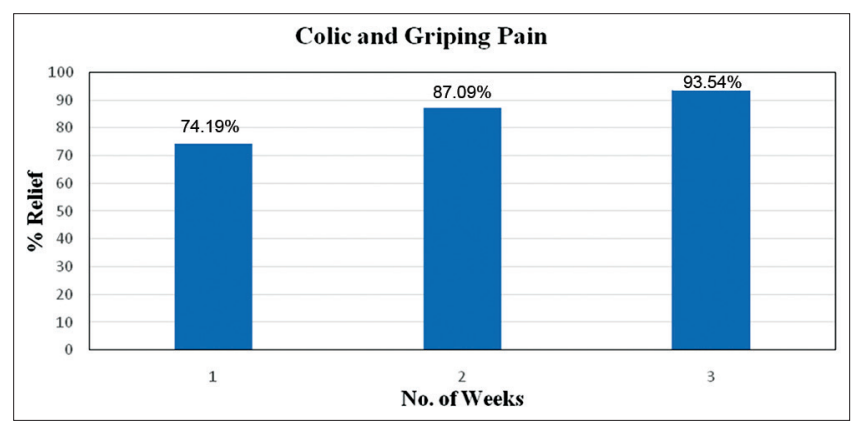

Fig. 1: Relief in colic and griping pain after consuming colicarmin plus syrup

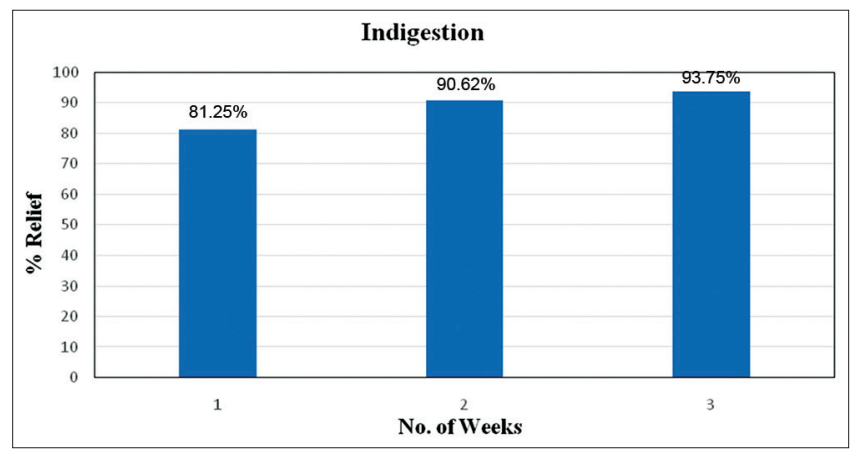

Fig. 2: Relief in indigestion after consuming colicarmin plus syrup

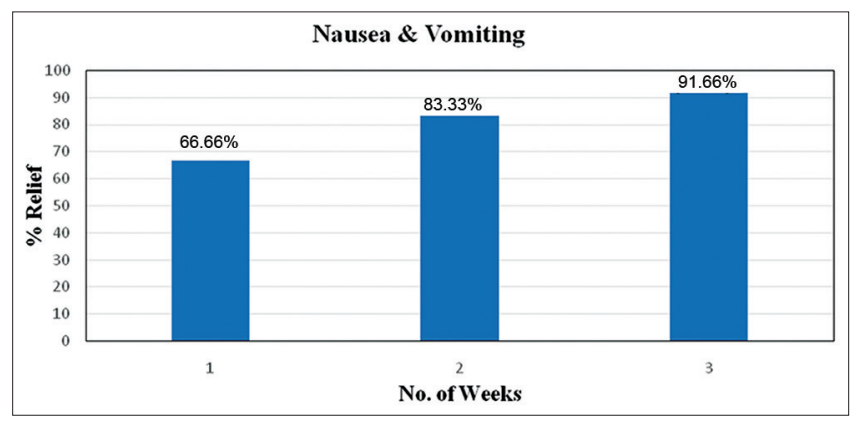

Fig. 3: Relief in nausea and vomiting after consuming colicarmin plus syrup

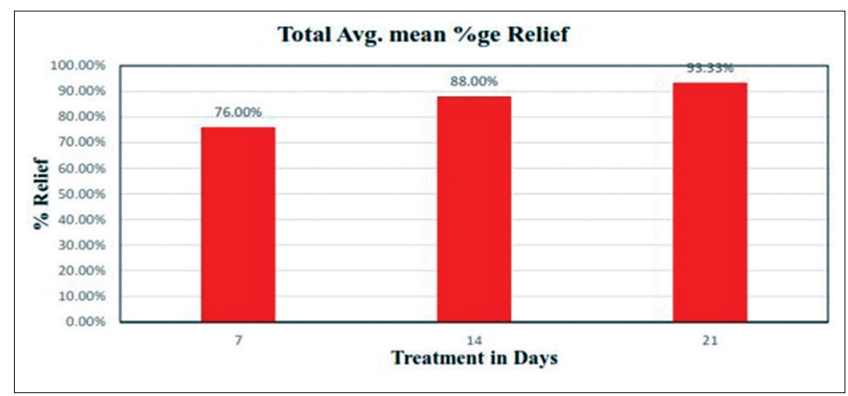

Fig. 4: Total average mean percentage relief after consuming colicarmin plus syrup
In the case of indigestion after the treatment of 21 days, $93.75 \%$ relief was observed (Fig. 2).

In the case of nausea and vomiting after the treatment of 21 days, 91.66\% relief was observed (Fig. 3).

In the case of Total avg. mean \% relief, the results after the treatment of 21 days showed $93.33 \%$ relief (Fig. 4)

\section{DISCUSSION}

As per current scenario gripes and gas, diarrhea, indigestion, nausea and vomiting are the common problem found into the children and

Table 1: Some herbs used in treatment of various abdominal disorders

\begin{tabular}{|c|c|}
\hline Herbs & Uses \\
\hline $\begin{array}{l}\text { Soya }(\text { Peucedanum } \\
\text { graveolens) }\end{array}$ & $\begin{array}{l}\text { Relieves intestinal spasms and griping, } \\
\text { helping to settle and prevent colic }\end{array}$ \\
\hline $\begin{array}{l}\text { Indrajav (Holarrhena } \\
\text { antidysenterica) }\end{array}$ & $\begin{array}{l}\text { Helps to improve the functioning of } \\
\text { digestive tract and tones the digestive } \\
\text { tract. Mainly useful in diarrhoea } \\
\text { intestinal worms and piles }\end{array}$ \\
\hline Hing (Ferula Foetida) & Intestinal gas and stomach upset \\
\hline $\begin{array}{l}\text { Kanta karanj } \\
\text { (Caesalpinia bonducella) }\end{array}$ & Abdominal disorders \\
\hline $\begin{array}{l}\text { Nimbuka sat } \\
\text { (Citrus medica) }\end{array}$ & Used in abdominal disorders \\
\hline $\begin{array}{l}\text { Sukshma ela } \\
\text { (Elettaria cardamomum) }\end{array}$ & Dysentery and digestive disorders \\
\hline $\begin{array}{l}\text { Sovarchal (unaqua } \\
\text { sodium chloride) }\end{array}$ & Clears constipation \\
\hline $\begin{array}{l}\text { Kulianjan } \\
\text { (Alpinia galangal) }\end{array}$ & $\begin{array}{l}\text { Stimulate appetite, cure nausea, } \\
\text { motion sickness and diarrhoea, sooth } \\
\text { stomach pain }\end{array}$ \\
\hline $\begin{array}{l}\text { Saidhav (sodium } \\
\text { chloride) }\end{array}$ & $\begin{array}{l}\text { Used in dyspepsia and abdominal } \\
\text { disorders }\end{array}$ \\
\hline
\end{tabular}

Table 2: Results are observed after 21 days of therapeutic dose for syrup

\begin{tabular}{|c|c|c|c|c|c|}
\hline \multirow[t]{2}{*}{ Indications } & \multirow{2}{*}{$\begin{array}{l}\text { Total } \\
\text { number of } \\
\text { patients }\end{array}$} & \multicolumn{3}{|c|}{ Patient during the treatment } & \multirow{2}{*}{$\begin{array}{l}\% \\
\text { results }\end{array}$} \\
\hline & & $1^{\text {st }}$ week & $2^{\text {nd }}$ week & $3^{\text {rd }}$ week & \\
\hline $\begin{array}{l}\text { Colic and } \\
\text { griping pain }\end{array}$ & 31 & 23 & 4 & 2 & 93.54 \\
\hline Indigestion & 32 & 26 & 3 & 1 & 93.75 \\
\hline $\begin{array}{l}\text { Nausea and } \\
\text { vomiting }\end{array}$ & 12 & 8 & 2 & 1 & 91.66 \\
\hline Total & 75 & 57 & 9 & 4 & 93.33 \\
\hline
\end{tabular}

Table 3: Distribution of the patients on basis of age group

\begin{tabular}{lll}
\hline Age of patients & & \\
\hline Total number of patients & Children & Adults \\
\hline 75 & 30 & 45 \\
\hline
\end{tabular}

Table 4: Distribution of the patients on basis of sex group

\begin{tabular}{lllll}
\hline \multicolumn{2}{l}{ Sex distribution of patients } & & \\
\hline Children & & & Adults & \\
\cline { 5 - 5 } Male & Female & & Male & Female \\
\hline 20 & 10 & 27 & 18 \\
\hline
\end{tabular}


Table 5: Some ingredients used in the treatment of various abdominal disorders

\begin{tabular}{ll}
\hline Herbs & Clinical efficacy \\
\hline $\begin{array}{l}\text { Sovarchal (Unaqua } \\
\text { sodium chloride), Soya } \\
\text { (Peucedanum graveolens) }\end{array}$ & $\begin{array}{l}\text { Reinforce body's own } \\
\text { secretion of digestive enzymes }\end{array}$ \\
$\begin{array}{l}\text { Hing (Ferula Foetida), } \\
\text { Saindhav (sodium chloride) }\end{array}$ & $\begin{array}{l}\text { Restore gastrointestinal } \\
\text { motility and expel unwanted } \\
\text { gases }\end{array}$ \\
$\begin{array}{l}\text { NimbuKa sat (Citrus medica), } \\
\text { Indravaj (Holarrhena }\end{array}$ & $\begin{array}{l}\text { Treating abdominal colic, } \\
\text { digestive disorders, and piles }\end{array}$ \\
$\begin{array}{l}\text { Kanta karanj } \\
\text { (Ceasalpinia bonducella) }\end{array}$ & Restore colic and griping pain \\
\hline
\end{tabular}

adults. There have to concern about safety profile with effective therapeutic dosage.

In these conditions, we have done the clinical trial to confirm the efficacy of colicarmin plus syrup into the different age groups of patients with different problems.

The clinical study was found effective in all indications as can be seen from the above data. Quick relief from colic and griping pain was the direct evidence of the effectiveness of colicarmin plus syrup.

Clinical efficacy on herbal preparation of colicarmin plus syrup is because of the following ingredients.

The well balanced colicarmin plus syrup offers multiple benefits such as digestive, carminative, anthelmintic, antiflatulent, and antispasmodic and is very palatable, without any side effects.

\section{CONCLUSION}

During this clinical trial on 75, a number of patients for colicarmin plus syrup with the prescribed therapeutic dosage of colicarmin plus syrup; we found that out of 31 patients suffering from colic and griping pain almost more than $60 \%$ patients got relief in just 7 days.

In case of indigestion 26 patients out of 32 patients got relief in just 07 days. Moreover, out of 12 patients suffering from nausea and vomiting more than $60 \%$ patients were cured in 7 days. After 21 days treatment 93.33\% mean results for colicarmin plus syrup were observed as total average \% relief in different indications (Table 5)

Considering the result of the trail report, it may be concluded that colicarmin plus syrup is one Ayurvedic formulation with five benefits such as digestive, carminative, anthelmintic, antiflatulent, and antispasmodic without any side effects. Moreover, further elaborated and large-scale studies are recommended.

\section{REFERENCES}

1. Herman M, Le A. The Crying Infant. Emerg Med Clin North Am 2007;25(4):1137-59.

2. Allen JS. Acute Intestinal Indigestion - Infancy and Childhood. J Natl Med Assoc 1911;3(3):214-6.

3. Akman I, Kusçu K, Ozdemir N, Yurdakul Z, Solakoglu M, Orhan L, et al. Mothers' postpartum psychological adjustment and infantile colic. Arch Dis Child 2006;91(5):417-9.

4. Khare CP. Indian Medicinal Plants. New York: Springer-Verlag Publications; 2007. p. 51

5. Khare CP. Indian Medicinal Plants. New York: Springer-Verlag Publications; 2007. p. 312.

6. Khare CP. Indian Medicinal Plants. New York: Springer-Verlag Publications; 2007. p. 261.

7. Khare CP. Indian Medicinal Plants. New York: Springer-Verlag Publications; 2007. p. 106.

8. Khare CP. Indian Medicinal Plants. New York: Springer-Verlag Publications; 2007. p. 156.

9. Khare CP. Indian Medicinal Plants. New York: Springer-Verlag Publications; 2007. p. 234.

10. Nadkarni KM. The Indian Materia Medica. Vol. I. Bombay: Popular Prakashan Pvt., Ltd; 1976. p. 77.

11. Nadkarni KM. The Indian Materia Medica. Vol. II. Bombay: Popular Prakashan Pvt., Ltd.; 1976. p. 100. 